\title{
EWOLUCJA POLSKICH UREGULOWAŃ DOTYCZĄCYCH MEDIACJI W SPRAWACH KARNYCH NA TLE STANDARDÓW EUROPEJSKICH
}

Mediacją $\mathrm{w}$ sprawach karnych zainteresowano się na forum międzynarodowym w latach 80 . XX w., czego pokłosiem było uchwalenie pierwszych aktów prawa międzynarodowego zalecających sygnatariuszom wzięcie pod uwagę metod rozwiązywania konfliktów karnych alternatywnych wobec retrybutywnego systemu wymiaru sprawiedliwości ${ }^{1}$. W obszarze europejskim przodującą instytucją pod względem działalności prawotwórczej w tym zakresie jest Rada Europy, która na przestrzeni kilkunastu lat przyjęła szereg rekomendacji odwołujących się do elementów instytucji sprawiedliwości naprawczej². Wśród nich należy zwrócić uwagę przede wszystkim na dwa dokumenty: Rekomendację Nr R (85) 11 w sprawie pozycji ofiary w prawie i procesie karnym z dnia 28 czerwca 1985 r. oraz Rekomendację $\mathrm{Nr}$ R (87) $21 \mathrm{w}$ sprawie zapobiegania wiktymizacji i pomocy dla ofiar przestępstw z dnia 17 września 1987 r. ${ }^{3}$ Co prawda, rekomendacje powyższe traktowały mediację w sposób bardzo ogólny, nie ustanawiały zasad ani procedur, wskazując jedynie na konieczność rozwijania programów eksperymentalnych, jednocześnie jednak zwracały uwagę na konieczność zabezpieczenia praw i interesów ofiar i sprawców. Formułowanie jakichkolwiek konkretnych standardów w ówczesnym stanie wiedzy na temat alternatywnych sposobów reakcji na przestępstwo było przedwczesne, jako że w żadnym kraju europejskim odpowiednie projekty nie wyszły poza fazę eksperymentalną.

Zob. E. Bieńkowska, Postępowanie mediacyjno-restytucyjne jako sposób rozwiązania konfliktu między ofiarą i sprawcą przestępstwa: standardy międzynarodowe i perspektywy w Polsce, (w:) E. Bieńkowska (red.), Teoria i praktyka pojednania ofiary ze sprawcą. Materiały konferencji międzynarodowej (Warszawa, 26-27 styczeń 1995), Warszawa 1995, s. 22-27.

2 Zob. A. Rękas, Mediacja w polskim prawie karnym, Warszawa 2004, s. 6.

3 Polski tekst obu Rekomendacji oraz Raportów wyjaśniających Europejskiego Komitetu do spraw Problemów Przestępczości, (w:) E. Bieńkowska, C. Kulesza, Europejskie standardy kształtowania sytuacji ofiar przestępstw, Białystok 1997, s. 90-149. 
W takich realiach wprowadzone zostały w ramach nowego Kodeksu postępowania karnego (k.p.k.) z 1997 r. pierwsze uregulowania dotyczące mediacji w sprawach karnych w Polsce. Nadmienić należy, że nie zostały one poprzedzone żadnym programem eksperymentalnym jak w innych państwach Europy Zachodniej. Jedynym i to bardzo krótkim doświadczeniem był program eksperymentalny w zakresie mediacji w sprawach czynów karalnych nieletnich opracowany w 1995 r. przez Zespół do spraw Wprowadzenia Mediacji w Polsce ${ }^{4}$. Środowiska działające na rzecz mediacji w Polsce inspirowały się w znacznym stopniu rozwojem tej instytucji za granicą niż w naszych rodzimych realiach. Nie budzi więc zdziwienia fakt, że mediacja została wprowadzona do k.p.k. w ostatniej chwili w sposób pośpieszny i niejako przypadkowy ${ }^{5}$. Za dość przypadkowe uznać należy również zamieszczenie omawianej instytucji wśród przepisów dotyczących postępowania przygotowawczego, tj. w ówczesnym art. 320 k.p.k.

O ile wprowadzenie instytucji mediacji do polskiego postępowania karnego zostało przyjęte $\mathrm{z}$ aprobatą, o tyle szczegółowe rozwiązania spotkały się z krytyką zarówno doktryny, jak i praktyków ${ }^{6}$, a o wadliwości ówczesnych rozwiązań świadczą dobitnie statystyki dotyczące stosowania tej instytucji w pierwszych latach jej funkcjonowania. $\mathrm{W}$ trakcie prac nad nowym k.p.k. nie podejmowano jednak dyskusji na temat zgodności projektowanych przepisów ze standardami międzynarodowymi, gdyż te ostatnie w tym okresie nie zostały jeszcze zebrane w postaci jednolitego dokumentu.

Najważniejsza norma dotycząca mediacji zawarta była w art. $320 \S 1$ k.p.k., według którego jeżeli ma to znaczenie dla wystąpienia do sądu z odpowiednim wnioskiem, prokurator może, z inicjatywy lub za zgodą stron, skierować sprawę do instytucji lub osoby godnej zaufania $\mathrm{w}$ celu przeprowadzenia postępowania mediacyjnego między podejrzanym i pokrzywdzonym. Umiejscowienie tego przepisu w systematyce k.p.k. ograniczało możliwość zastosowania mediacji w postępowaniu publicznoskargowym jedynie do postępowania przygotowawczego oraz na podstawie art. 339 § 4 k.p.k. do fazy wstępnej kontroli oskarżenia w postępowaniu sądowym ${ }^{7}$. W późniejszych fazach postępowania jurysdykcyjnego zastosowanie mediacji ze względu na brak podstawy prawnej ku temu nie było możliwe.

Lakoniczne uregulowania k.p.k. uzupełnione zostały Rozporządzeniem Ministra Sprawiedliwości w sprawie warunków, jakim powinny odpowiadać instytucje

5

6

7

Zob. B. Czarnecka-Dzialuk, D. Wójcik, Mediacja w sprawach nieletnich w świetle teorii i badań, Warszawa 2001. Zob. E. Bieńkowska, Mediacja między ofiarą i przestępcą, „Monitor Prawniczy” 1998, nr 10, s. 375-376.

Zob. np. A. Rękas, Mediacja w praktyce wymiaru sprawiedliwości - szanse i zagrożenia, (w:) Konferencja naukowa: „Mediacja w polskiej rzeczywistości” (11 września 2002 r.), Warszawa 2003, s. 28.

Tak m.in. D. Wójcik, Perspektywy rozwoju mediacji, (w:) Konferencja naukowa: „Mediacja w polskiej rzeczywistości" (11 września 2002 r.), Warszawa 2003, s. 85. Odmienne stanowisko zajęła M. Płatek dopuszczając możliwość kierowania sprawy do mediacji do czasu pierwszego przesłuchania na rozprawie głównej oraz w postępowaniu wykonawczym - zob. M. Płatek, Mediacja w postępowaniu wykonawczym. Argumenty zgłoszone na rzecz i przeciw mediacji na tle doświadczeń międzynarodowych, (w:) Konferencja naukowa: „Mediacja w polskiej rzeczywistości” (11 września 2002 r.), Warszawa 2003, s. 55. 
i osoby uprawnione do przeprowadzenia mediacji, zakresu i warunków udostępniania im akt sprawy oraz zasad i tryb sporządzania sprawozdania z przebiegu i wyników postępowania mediacyjnego wydanym w dniu 14 sierpnia 1998 r., ${ }^{8}$ jednak podobnie jak w przypadku k.p.k., również unormowania rozporządzenia krytykowane były jako niepełne i niespełniające standardów międzynarodowych. Do najpoważniejszych wad zgodnie zaliczano brak wskazania podstawowych zasad mediacji, trybu jej przeprowadzania, brak obowiązku przekazywania uczestnikom stosownej informacji przez mediatora, brak obowiązku odbycia specjalistycznych szkoleń oraz brak procedur weryfikacji wiedzy kandydatów na mediatorów czy zagrażający poufności mediacji obowiązek przedstawiania przez mediatora w końcowym sprawozdaniu informacji o przebiegu mediacji, niezneutralizowany zakazem dowodowym przesłuchania mediatora co do okoliczności, o których dowiedział się $\mathrm{w}$ trakcie prowadzenia mediacji ${ }^{9}$. To ostatnie teoretycznie groziło ewentualnością wykorzystywania mediatora jako źródła dowodowego w postępowaniu karnym.

Problem konieczności nowelizacji przepisów dotyczących mediacji w sprawach karnych stał się szczególnie palący w momencie przyjęcia Rekomendacji Rady Europy Nr R (99)19 o mediacji w sprawach karnych z dnia 15 września 1999 r., ${ }^{10}$ a więc ledwie po roku od wejścia w życie k.p.k. Rekomendacja w kompleksowy sposób określiła zasady systemowe i proceduralne stosowania mediacji między ofiarą i sprawcą w sprawach karnych wieńcząc kilkunastoletni proces kształtowania standardów mediacyjnych.

Załącznik do Rekomendacji Nr R (99)19 składa się z sześciu rozdziałów zawierających definicję mediacji, ogólne zasady mediacji, zasady dotyczące podstaw prawnych mediacji, zasady działania wymiaru sprawiedliwości w odniesieniu do mediacji, zasady działania instytucji mediacyjnych, w tym dotyczące standardów, jakimi powinny kierować się te instytucje, kwalifikacji i szkoleń mediatorów oraz samego postępowania mediacyjnego i jego wyniku, dyrektywy stałego rozwijania mediacji. Do ogólnych zasad mediacji Rekomendacja zalicza dobrowolność mediacji, poufność, powszechną dostępność mediacji oraz autonomię instytucji mediacyjnych. O ile polskie przepisy zasadniczo były skorelowane z zasadą dobrowolności wyartykułowaną w pkt 1 (,Mediacja w sprawach karnych może mieć miejsce tylko

$8 \quad$ Dz.U. Nr 111, poz. 701.

9 Zob. m.in.: J. Waluk, M. Kruk, Problemy wprowadzania mediacji w Polsce. Mediacja w prawie karnym - pierwsze doświadczenia, (w:) Probacyjne środki polityki karnej - stan i perspektywy. Materiały z konferencji zorganizowanej przez Komisję Praw Człowieka i Praworządności, 20-21 października 2000 r., Warszawa 2001, s. 282-283; A. Murzynowski, Mediacja w toku postępowania przygotowawczego, (w:) Probacyjne środki polityki karnej - stan i perspektywy. Materiały z konferencji zorganizowanej przez Komisję Praw Człowieka i Praworządności, 20-21 października 2000 r., Warszawa 2001, s. 292-293; A. Rękas, Mediacja w praktyce wymiaru..., op. cit., s. 26-28; D. Wójcik, Perspektywy rozwoju mediacji..., op. cit., s. 87-88.

10 Polski przekład Rekomendacji oraz komentarza, (w:) Rekomendacja Nr R (99) 19 Komitetu Ministrów [Rady Europy] dla państw członkowskich o mediacji w sprawach karnych (przyjęta przez Komitet Ministrów dnia 15 września 1999 r. na 679 posiedzeniu przedstawicieli ministrów) i komentarz, Archiwum Kryminologii 1999-2000, t. XXV, s. 225-243. Zob. również E. Bieńkowska, Europejskie standardy mediacji w sprawach karnych, „Jurysta” 2008 , nr 5, s. $11-16$. 
jeśli strony dobrowolnie wyrażają na to zgodę. Strony powinny mieć możliwość wycofania takiej zgody w każdym czasie w trakcie mediacji”) i pkt 31 („Ugoda powinna być ustalona dobrowolnie przez strony. Powinna zawierać tylko rozsądne i proporcjonalne zobowiązania") oraz zasadą autonomii instytucji mediacyjnych (pkt 5), o tyle jedynie częściowo były zgodne z zaleceniami dotyczącymi poufności i powszechnej dostępności.

Zasada poufności mediacji dotyczy dwóch aspektów. Po pierwsze nie można powoływać się na treść rozmów prowadzonych podczas mediacji, chyba że strony wyrażą na to zgodę (pkt 2 Rekomendacji), zaś sprawozdanie mediatora o podjętych działaniach i o wyniku mediacji przedkładane organom wymiaru sprawiedliwości nie może ujawniać przebiegu spotkania mediacyjnego ani też zawierać żadnych sądów, co do zachowania stron w trakcie mediacji (pkt 32). Mediator powinien jednak przekazywać organom procesowym informacje o szczególnie poważnych zbrodniach, które wyszły na jaw w trakcie mediacji (punkt 30 Rekomendacji). Po drugie postępowanie mediacyjne toczy się przy drzwiach zamkniętych (pkt 29). Jak już wcześniej wspomniano, ówczesne przepisy ani wprost nie statuowały zasady poufności ani nie gwarantowały, że informacje dotyczące czynu ujawnione w trakcie postępowania mediacyjnego nie przenikną do procesu karnego w postaci materiału dowodowego.

W przypadku zasady powszechnej dostępności mediacji, pierwszy z jej aspektów, tj. zapewnienie pełnego zasięgu na terytorium kraju oraz równe możliwości dostępu do usług mediacyjnych przez obywateli (pkt 3 Rekomendacji) został dostatecznie zagwarantowany w prawie krajowym. Bardziej złożona sytuacja dotyczyła drugiego z aspektów, czyli dostępności mediacji we wszystkich stadiach postępowania karnego (pkt 4 Rekomendacji). Omawiany wyżej art. 320 k.p.k. oraz art. $339 \S 4$ k.p.k. ograniczały możliwość stosowania mediacji w postępowaniu rozpoznawczym tylko do fazy merytorycznego badania oskarżenia, z kolei przepisy art. $489 \S 2$ oraz $492 \S 2$ k.p.k. dopuszczały mediację w postępowaniu prywatnoskargowym. Ustawodawca uchylił się nadto od ustanowienia klarownych uregulowań dotyczących stosowania mediacji w postępowaniu wykonawczym, który to stan trwa do chwili obecnej wzbudzając spore kontrowersje doktryny. Zwolennicy możliwości stosowania mediacji w postępowaniu wykonawczym powołują się przede wszystkim na art. $1 \S 2$ Kodeksu karnego wykonawczego (k.k.w.), nakazujący w postępowaniu wykonawczym w kwestiach nie uregulowanych w k.k.w. stosować odpowiednio przepisy k.p.k. (które przewidują przecież instytucję mediacji) ${ }^{11}$. Ponadto sugeruje się wykorzystanie art. 95 k.k.w., na podstawie którego mediację należy uważać za przykład działania, jakie przedsiębierze się dla przygotowania skazanego do powrotu do społeczeństwa ${ }^{12}$ oraz uznanie jej za indywidualny środek oddziaływania

12 Zob. M. Płatek, Mediacja w postępowaniu wykonawczym..., op. cit., s. 55. 
wychowawczego zgodnie z art. 67, art. $89 \S 1$ i 2 oraz art. 95 k.k.w. ${ }^{13}$ Obecnie jedynym przepisem k.k.w., który expressis verbis wymienia mediację, jest znowelizowany ustawą z dnia 24 lipca 2003 r. o zmianie ustawy - Kodeks karny wykonawczy oraz niektórych innych ustaw ${ }^{14}$ art. $162 \S 1$, nakazujący uwzględnianie przez sąd penitencjarny przy orzekaniu o warunkowym przedterminowym zwolnieniu skazanego ugody zawartej w wyniku mediacji. Oponenci z kolei twierdzą, że nie ma możliwości prowadzenia mediacji w postępowaniu wykonawczym, a art. $162 \S 1$ k.k.w. dotyczy wyłącznie mediacji przeprowadzonej wcześniej w postępowaniu przygotowawczym lub sądowym ${ }^{15}$. Trudno zgodzić się z tym ostatnim stanowiskiem, gdyż należałoby wtedy przyjąć dopuszczalność wzięcia pod uwagę dwukrotnie wyników tego samego postępowania mediacyjnego - najpierw przy wydawaniu decyzji procesowej przez prokuratora lub sąd, a ponownie w postępowaniu wykonawczym.

Działalność prawotwórcza organów Unii Europejskiej w zakresie mediacji w sprawach karnych prezentuje się skromniej niż Rady Europy, zaś same unormowania są bardzo ogólnikowe. W chwili wydania pierwszego w tej materii dokumentu, tj. Decyzji ramowej Rady Unii Europejskiej z dnia 15 marca 2001 r. o pozycji ofiary w postępowaniu karnym $(2001 / 220 / \mathrm{WSiSW})^{16}$, nałożone przez nią na państwa obowiązki były przez Polskę spełnione, choć nie była ona w tym czasie jeszcze członkiem Unii Europejskiej. Decyzja ramowa w art. 10 ust. 1 obligowała państwa członkowskie do zadbania o to, aby popierać prowadzenie mediacji w ramach postępowania karnego w przypadku przestępstw odpowiednich dla tej instytucji, natomiast w ust. 2 nakazywała państwom członkowskim zadbać o to, aby w postępowaniu karnym zostało uwzględnione porozumienie między sprawcą i ofiarą, osiągnięte w czasie mediacji, przy czym ustawodawstwom krajowym lub praktyce pozostawiono kwestię sprecyzowania, jakie typy przestępstw nadają się do mediacji. Nie wywołując bezpośredniego skutku, a jedynie określając rezultat, jaki ma zostać osiągnięty, Decyzja ramowa zakreśliła termin 22 marca 2006 r. do wprowadzenia odpowiednich przepisów krajowych niezbędnych do realizacji art. 10.

Mimo możliwości wcześniejszej zmiany krytykowanych przepisów, polski ustawodawca zwlekał ponad trzy lata od uchwalenia Rekomendacji Nr R (99)19 i stosowne zmiany przeprowadził w pierwszej kompleksowej nowelizacji k.p.k. - ustawie z dnia 10 stycznia 2003 r. o zmianie ustawy - Kodeks postępowania karnego, ustawy - Przepisy wprowadzające Kodeks postępowania karnego, ustawy

13 Zob.: E. Dobiejewska, Mediacja po wyroku, problemy i szanse dla wymiaru sprawiedliwości, (w:) Probacyjne środki polityki karnej - stan i perspektywy. Materiały z konferencji zorganizowanej przez Komisję Praw Człowieka i Praworządności, 20-21 października 2000 r., Warszawa 2001, s. 325; E. Dobiejewska, Stan mediacji w Polsce, „Mediator” 2003, nr 4, s. 48.

14 Dz.U. Nr 142, poz. 1380.

15 Zob.: K. Winiarek, Mediacja po wyroku..., op. cit., s. 199; D. Wójcik, Poglądy sędziów na temat mediacji w sprawach karnych, (w:) K. Krajewski (red.), Nauki penalne wobec problemów współczesnej przestępczości. Księga jubileuszowa z okazji 70. Rocznicy urodzin Profesora Andrzeja Gaberle, Warszawa-Kraków 2007, s. 563. Official Journal L 082, 22/03/2001 P. 0001 - 0004. Dz. Urz. UE L 082 z 22.03.2001, s. 1-4. 
o świadku koronnym oraz ustawy o ochronie informacji niejawnych ${ }^{17}$. Nowelizacja, choć mocno spóźniona, nie dostosowała całkowicie polskiego prawa do standardów Rekomendacji. Co więcej, procedowano nad nią niezbyt uważnie pozostawiając w dwóch miejscach (art. 339 § 4 i art. 489 § 2 k.p.k.) odesłania do uchylonego właśnie art. 320 k.p.k. (!), co następnie naprawiono jeszcze w czasie trwania vacatio legis nowych przepisów przy okazji uchwalania ustawy z dnia 13 czerwca $2003 \mathrm{r}$. o zmianie ustawy - Kodeks karny oraz niektórych innych ustaw ${ }^{18}$.

Nowelizacja z jednej strony naprawiła jawne niedociągnięcia dotychczasowych unormowań, co zaprocentowało dynamicznym wzrostem liczby postępowań mediacyjnych w kolejnych latach, $\mathrm{z}$ drugiej jednak strony w dalszym ciągu pozostały bez echa postulaty wprowadzenia gwarantującego zasadę poufności bezwzględnego zakazu dowodowego przesłuchania mediatora co do faktów, o których dowiedział się prowadząc mediację, na podobieństwo zawartego w art. 178 k.p.k. zakazu przesłuchania w charakterze świadka obrońcy lub adwokata osoby zatrzymanej na okoliczność faktów, o których dowiedział się prowadząc sprawę oraz duchownego na okoliczność faktów, o których dowiedział się w trakcie spowiedzi. Pozostawiono również bez zmian art. 107 k.p.k., który nie przewidywał możliwości uznania ugody zawartej w postępowaniu mediacyjnym za tytuł egzekucyjny, a w konsekwencji, po nadaniu przez sąd klauzuli wykonalności, za tytuł wykonawczy, choć pkt 17 Rekomendacji stanowi, że wykonanie zobowiązań wynikających z ugody mediacyjnej (osiągniętego porozumienia) powinno mieć taki sam status jak postanowienie lub wyrok i powinno wyłączać ściganie w odniesieniu do tych samych faktów według zasady ne bis in idem. Ustawodawca wówczas nie przewidział odrębnej podstawy prawnej wyłączającej ściganie czynu, co do którego mediacja przyniosła pozytywne efekty. Uniwersalność omawianej instytucji oraz jej dostosowanie do zasady powszechnej dostępności w aspekcie pkt 4 Rekomendacji Nr R (99) 19 podkreślone zostało przeniesieniem jej do art. 23a k.p.k., tj. do przepisów wstępnych. Od tej pory niewątpliwa stała się możliwość stosowania mediacji nie tylko w postępowaniu przygotowawczym, ale również w całym postępowaniu jurysdykcyjnym, nie wyłączając postępowania odwoławczego.

Po ponad dekadzie obowiązywania, Decyzja ramowa Rady Unii Europejskiej o pozycji ofiary w postępowaniu karnym została zastąpiona Dyrektywą Parlamentu Europejskiego i Rady 2012/29/UE z dnia 25 października 2012 r. ustanawiającą normy minimalne $\mathrm{w}$ zakresie praw, wsparcia i ochrony ofiar przestępstw oraz zastępującą decyzję ramową Rady 2001/220/WSiSW ${ }^{19}$. Nowy dokument w art. 12 uszczegółowił - co prawda nie tak dalece, jak Rekomendacja Rady Europy Nr R (99)19 - gwarancje ofiar przestępstw w zakresie korzystania z instytucji sprawiedliwości naprawczej. Dyrektywa nakazuje państwom członkowskim podjęcie odpowiednich

17 Dz.U. z 2003 r. Nr 17, poz. 155.

18 Dz.U. z 2003 r. Nr 111, poz. 1061

19 Dz. Urz. UE L 315 z 14.11.2012, s. 57-73. 
środków, które stosowane podczas świadczenia usług w zakresie sprawiedliwości naprawczej zabezpieczą ofiarę przed wiktymizacją wtórną i ponowną, zastraszaniem oraz odwetem państwa. Środki takie powinny spełniać co najmniej następujące warunki:

a) usługi w zakresie sprawiedliwości naprawczej stosuje się tylko wtedy, gdy leżą w interesie ofiary, biorąc pod uwagę względy bezpieczeństwa, i opierają się one na dobrowolnej i świadomej zgodzie wyrażonej przez ofiarę, którą to zgodę można w każdej chwili wycofać;

b) przed wyrażeniem zgody na uczestnictwo w procesie sprawiedliwości naprawczej ofiara otrzymuje pełne i obiektywne informacje na temat tego procesu i jego potencjalnych rezultatów, jak również informacje o trybie nadzoru nad realizacją jakiejkolwiek ugody;

c) sprawca musiał wcześniej potwierdzić podstawowe fakty związane ze sprawą;

d) każda ugoda jest wynikiem dobrowolnego porozumienia i może być uwzględniona we wszelkich dalszych postępowaniach karnych;

e) rozmowy prowadzone w ramach czynności sprawiedliwości naprawczej, które nie są prowadzone publicznie, mają charakter poufny i nie są następnie ujawniane, chyba że strony wyrażą na to zgodę lub wymaga tego prawo krajowe ze względu na nadrzędny interes publiczny.

Dyrektywa obliguje jednocześnie państwa członkowskie do ułatwiania kierowania spraw, w odpowiednich przypadkach, do służb świadczących usługi w zakresie sprawiedliwości naprawczej, również poprzez ustanowienie procedur lub wytycznych dotyczących warunków takiego kierowania. Istotnym jest fakt, że w odróżnieniu od Rekomendacji, powyższa Dyrektywa zobowiązuje na podstawie art. 27 ust. 1 państwa członkowskie UE do wprowadzenia w życie przepisów ustawowych, wykonawczych i administracyjnych niezbędnych do wykonania tejże Dyrektywy w terminie do dnia 16 listopada 2015 r. Należy stwierdzić, że Polska, dzięki zmianom przepisów uchwalonym w dniu 27 września 2013 r. w ramach gruntownej nowelizacji k.p.k. ${ }^{20}$, od dnia wejścia w życie tych zmian, czyli od 1 lipca 2015 r. będzie spełniać wyżej wymienione warunki minimalne ${ }^{21}$. Ponadto wypełnione zostaną również te zalecenia Rekomendacji Rady Europy Nr R (99) 19, co do których polski ustawodawca nowelizując k.p.k. w roku 2003 zachował wstrzemięźliwość. Stworzenie dzięki nowelizacji z 2013 r. nowych standardów ustawowych poprzez wyraźne ujęcie w k.p.k. zasady dobrowolności, poufności, bezstronności, zakazu dowodowego

20 Ustawa z dnia 27 września 2013 r. o zmianie ustawy - Kodeks postępowania karnego oraz niektórych innych ustaw (Dz.U. z 2013 r., poz. 1247).

21 Za dyskusyjny uznać należy wymóg wcześniejszego potwierdzenia przez sprawcę podstawowych faktów związanych ze sprawą - zob. C. Kulesza, D. Kużelewski, Mediacja jutro - k.p.k. oczekuje na zmiany, (w:) L. Mazowiecka (red.), Mediacja w praktyce prokuratorskiej - dziś i jutro, Warszawa 2012, s. 66-67. 
przesłuchania mediatora w charakterze świadka na okoliczność informacji, o których dowiedział się $\mathrm{w}$ trakcie prowadzenia mediacji, obowiązku pouczania stron o ich uprawnieniach oraz informowania o celach i zasadach postępowania mediacyjnego, zrównanie ugody zawartej w postępowaniu mediacyjnym z ugodą zawartą przed sądem co do możliwości nadania klauzuli wykonalności niewątpliwie przenosi przepisy dotyczące mediacji w sprawach karnych na wyższy poziom gwarancyjności. Pozostaje mieć nadzieję, że w niedalekiej przyszłości ustawodawca zdecyduje się na wprowadzenie expressis verbis mediacji do k.k.w., usuwając w ten sposób ostatnie wątpliwości co do zgodności polskich przepisów ze standardami europejskimi. 


\section{THE EVOLUTION OF POLISH REGULATIONS CONCERNING MEDIATION IN PENAL MATTERS AGAINST THE BACKGROUND OF EUROPEAN STANDARDS}

Within the European area it is the Council of Europe that leads in terms of lawmaking activity in the field of mediation in criminal cases. It has adopted for the last several years a series of recommendations that refer to restorative justice institutions. The most important of these is Recommendation No. R (99) 19 of the Committee of Ministers to Member States Concerning Mediation in Penal Matters of 15 September 1999, which comprehensively defined the rules and guarantees for mediation in criminal cases. The Recommendation lists as key principles of voluntary consent to participate, confidentiality, universal availability and the autonomy of mediation services within the criminal justice system. The European Union harmonizes legislations on mediation slightly slower. In recent times, Council Framework Decision of 15 March 2001 on the standing of victims in criminal proceedings has been replaced by a more detailed Directive 2012/29/EU of the European Parliament and of the Council of 25 October 2012, establishing minimum standards on the rights, support and protection of victims of crime. The Directive sets minimum standards on the right to safeguards in the context of restorative justice services. Polish legislation on mediation in criminal cases has evolved from initially being very unsuccessful and laconic into something more and more complex at the level of the act. Two comprehensive amendment acts to the Code of Criminal Procedure enacted in 2003 and 2013, modified and adapted regulations related to mediation to European standards.

Keywords: mediation, recommendation, directive, European standards, European Union, Council of Europe 